\title{
Konstruksi Berita Penggerebekan Asrama Mahasiswa Papua Surabaya Di TvOne
}

\author{
Dwi Devita, Muhammad Gafar Yoedtadi \\ dwi.915160064@stu.untar.ac.id,Gafary@fikom.untar.ac.id \\ Fakultas Ilmu Komunikasi Universitas Tarumanagara
}

\begin{abstract}
This study discusses the news frame on TvOne regarding the case of a Papua student hostel raid in Surabaya. This research uses news framing analysis method by William A. Gamson and Andre Modigliani media. Where ideally data in the form of statements can prove the selection and highlighting of certain aspects of a reality actually occur in the media. The raid news was taken according to the day of the case, which was 17 August 2019. The framing element of this news was presented in many forms, from the news script, the selection of titles and news supporting information to the statement of the source informants to strengthen the alleged framing of TvOne news. The results of this research, it can be concluded that there is a meaning of media participation in the TvOne news package.
\end{abstract}

Keyword: framing analysis, tvone news, william a. gamson and andre modigliani, standing

\begin{abstract}
Abstrak
Penelitian ini membahas tentang bingkai berita di TvOne mengenai kasus penggerebekan asrama mahasiswa Papua di Surabaya. Penelitian ini menggunakan metode analisi framing berita oleh media William A. Gamson dan Andre Modigliani. Dimana idealnya data dalam bentuk pernyataan-pernyataan dapat membuktikan penyeleksian dan penyorotan aspek-aspek khusus dari suatu realita benar terjadi di media. Berita penggerebekan ini diambil menurut hari terjadinya kasus tersebut yaitu tanggal 17 Agustus 2019. Unsur framing pada berita ini ditampilkan dalam banyak bentuk baik dari naskah berita yang dibacakan, pemilihan judul dan informasi pendukung berita hingga pernyataan narasumber menjadi aspek penguat dugaan framing pada berita TvOne. Hasil penelitian ini, dapat disimpulkan terdapat makna keberpihakan media pada paket berita TvOne.
\end{abstract}

Kata Kunci : berita tvone, analisis framing, william a. gamson dan andre modigliani, keberpihakkan

\section{Pendahuluan}

Studi Nielsen pada 2018 menunjukkan bahwa meskipun durasi menonton TV masih tertinggi, yaitu rata-rata 4 jam 53 menit setiap harinya menjadikannya alasan terbaik kenapa tv masih menjadi media paling akurat untuk dijadikan objek penelitian. Oleh karenanya pemberitaan di media populer seperti TV harus terus dijaga objektivitas, independensi, dan keberimbangannya. Untuk itulah adanya undangundang yang bertugas menegakkan sepak terjang media salah satunya adalah UU No. 40 Tahun 1999 tentang Pers dan juga UU Nomor 32 Tahun 2002 Tentang Penyiaran.

Kecurigaan terjadinya framing pada pemberitaan TvOne bermula dengan tayangnya program berita, Berita Utama pada tanggal 17 Agustus lalu. Setelah media mengungkit tentang track record satu tahun lalu dimana di tanggal 1 Desember yang 
lalu penghuni asrama ini juga melakukan long march yang sempat memicu keributan dengan berbagai ormas di Surabaya. Terlebih media melaporkan saat insiden ini terjadi, penghuni asrama yang dihimbau untuk keluar asrama dan menjelaskan kejadian ini tetap tutup mulut dan mendekam di dalam asrama.

Dalam Farid 2016 hal.189 menyatakan bahwa suatu berita dapat dibedakan menjadi beberapa kategori yang disebut Rubrikasi. Hal ini mendukung bahwa berita pada media mana pun akan menggolongkan dirinya sesuai dengan subjeknya. TvOne menjadikannya sebagai TV yang bergerak di bidang sosial politik mengikuti sistem rubrik. Dalam proses penelitian ini tv berita sangat diharapkan dapat saling mencontoh dan menerapkan objektivitas ini. Karena sebuah media adalah institusi yang paling tidak boleh mengalami bias dalam prosesnya bekerjanya.

Media massa seolah memberitakan kemungkinan kuat yang baru diketahui akar dari permasalahannya adalah pengrusakan dan pembuangan bendera merah putih beserta tiangnya ke selokan ini dilakukan oleh penghuni asrama papua. Dengan membuat opini bahwa penghuni asrama ini dari awal memang tidak "menghargai" kedaulatan Indonesia dan lebih memilih mengakui diri mereka sebagai bagian dari rakyat Papua Barat dengan membawa insiden 1 tahun yang lalu. Padahal untuk bukti nyatanya sendiri seperti rekaman CCTV dan lain-lain belum ada. Dan tidak ada bukti kuat bahwa yang melakukan perbuatan ini adalah penghuni mahasiswa ini. Dengan ini media pun dapat dianggap telah menyeleweng UU Pers Pasal 5 Ayat 1 serta Pasal 3 Kode Etik Jurnalistik, dimana pers berkewajiban untuk menerapkan asas praduga tak bersalah serta tidak membuat fakta dan opini yang bersifat menghakimi.

Tentunya sangat merugikan masyarakat, karena media yang hakikatnya sebagai alat untuk menyalurkan informasi malah tidak dapat menahan dirinya untuk tidak menggiring opini publik pada salah satu pihak saja. Walaupun memang pada faktanya media di Indonesia setelah melalui zaman reformasi di tahun 1998 sudah menganut sistem pers bebas. Akan tetapi pers tidak boleh melupakan kode-kode jurnalistik yang sudah ditetapkan. Karena sedemikian besar kekuatan media hingga apa yang menjadi pemberitaan media akan dianggap sebagai suatu kebenaran oleh masyarakat.

Hal-hal seperti inilah yang sering tidak dikritisi dari sebuah media, alhasil hoax dan berbagai kemungkinan dapat terjadi dengan berbagai pemberitaan yang ada. Masyarakat yang merasa penasaran dengan suatu isu akan terus berusaha mencari informasi dengan cepat tanpa melakukan tinjauan lebih lanjut dan akan lebih buruk jika masyarakat melakukan share langsung yang tentu akan lebih sulit lagi ditahan arus penyaluran informasinya, baik itu dilakukan dari komunikasi antar pribadi maupun melalui media sosial. Dalam penelitian ini, peneliti ingin mengajak para budiman untuk turut kritis dalam pemberitaan di media televisi.

\section{Rumusan Masalah}

Berdasarkan latar belakang di atas, maka rumusan masalah pada penelitian ini adalah "Bagaimana TvOne menyajikan pemberitaan kasus penggerebekan asrama mahasiswa Papua di Surabaya?" dan "Bagaimana framing yang disajikan oleh TvOne mengenai kasus penggerebekan asrama mahasiswa Papua di Surabaya?"

\section{Tujuan Penelitian}

Untuk mengetahui (1) untuk mengetahui bagaimana TvOne dalam menyajikan pemberitaan kasus pengrusakan Merah Putih di asrama mahasiswa Papua di Surabaya 
Dwi Devita, Muhammad Gafar Yoedtadi: Konstruksi Berita Penggerebekan Asrama Mahasiswa Papua Surabaya Di TvOne

(2) untuk mengetahui bagaimana framing yang disajikan oleh TvOne mengenai kasus penggerebekan asrama mahasiswa Papua di Surabaya.

\section{Konsep Teori}

\section{Komunikasi Massa}

Komunikasi massa adalah proses komunikasi yang dilakukan melalui media massa dengan berbagai tujuan komunikasi dan untuk menyampaikan informasi kepada khalayak luas. Maka, unsur-unsur penting dalam komunikasi massa adalah: komunikator, media massa, informasi, gatekeeper (penjaga gawang), khalayak, dan feedback (umpan balik) (Bungin 2011).

\section{Media Massa}

Menurut Leksikon Komunikasi, media massa adalah "sarana untuk menyampaikan pesan yang berhubungan langsung dengan masyarakat luas misalnya radio, televisi, dan surat kabar". Menurut Cangara, media adalah alat atau sarana yang digunakan untuk menyampaikan pesan dari komunikator kepada khalayak, sedangkan pengertian media massa sendiri alat yang digunakan dalam penyampaian pesan dari sumber kepada khalayak dengan menggunakan alat-alat komunikasi seperti surat kabar, film, radio dan televisi (Cangara, 2010).

\section{Jurnalistik}

Definisi umum tentang jurnalistik menyatakan bahwa jurnalistik adalah kegiatan mencari, mengolah, dan menyampaikan berita kepada khalayak. Dalam definisi tersebut, perburuan berita menjadi tujuan yang paling penting bagi semua jurnalis atau pewarta berita.

\section{Objektivitas Media}

Kovach dan Rosenstiel menegaskan bahwa esensi dari independensi media adalah kepindahan dari kepatuhan kepada partai politik kepada kepentingan publik. Terdapat dua pandangan tentang independensi ruang redaksi. Pertama, bahwa independen tidak selalu sama dengan berpihak. Kedua, ada pandangan bahwa independen berarti tidak berpihak, mengutamakan netralitas.

\section{Konstruksi Realitas Sosial}

Konstruksi sosial merupakan sebuah teori sosiologi kontemporer yang dikenalkan oleh Peter L. Berger dan Thomas Luckman. Berger dan Luckman meyakini secara substantif bahwa realitas merupakan hasil ciptaan manusia kreatif melalui kekuatan konstruksi sosial terhadap dunia sosial di sekelilingnya.

\section{Framing Media}

Media bukan sekadar sasaran yang bebas karena media juga subyek yang melakukan konstruksi terhadap realitas, lengkap dengan pandangan bias dan pemihakannya (Eriyanto, 2002: 23). Sama halnya dengan framing yang terjadi pada media berita, di mana penulisnya melakukan penonjolan di sisi-sisi tertentu,

\section{Ideologi Media}

Ideologi dipandang sebagai kerangka berpikir tertentu yang dipakai individu untuk memandang realitas dan meresponnya. Shoemaker-Reese membahas bagaimana ideologi dapat digolongkan sebagai hal abstrak dapat mempengaruhi isi media, terutama ideologi yang berkuasa. Hal ini menggunakan asumsi Noam Chomsky dan Edward Herman bahwa media melayani dominasi elit.

\section{Hirarki Media}

Tidak akan pernah ada peneliti yang objektif terhadap realitas. Semua dari kita memiliki pengalaman, kepribadian, dan pengetahuan untuk menginterpretasi apa yang 
kita lihat. Yang paling bisa dilakukan, menurut keduanya, adalah membandingkan realitas media dengan realitas sosial.

\section{Metode Penelitian}

Penulis menggunakan pendekatan kualitatif dengan jenis deskriptif untuk penelitian ini. Penelitian kualitatif memusatkan pada kegiatan nyata. Peneliti menekankan catatan dengan deskripsi kalimat yang rinci, lengkap, mendalam yang menggambarkan situasi yang sebenarnya guna mendukung penyajian data. Oleh sebab itu penelitian kualitatif secara umum sering disebut sebagai pendekatan kualitatif deskriptif. Peneliti berusaha menganalisis data dalam berbagai nuansa sesuai bentuk aslinya seperti pada waktu dicatat atau dikumpulkan. Mukhtar (2013: 28) Teknik pengelolaan dan analisis data yang digunakan adalah analisis framing atau analisis bingkai model William A. Gamson yang memandang framing sebagai cara bercerita atau gugusan ide-ide yang terorganisir sedemikian rupa dan menghadirkan konstruksi makna peristiwa-peristiwa yang berkaitan dengan objek suatu wacana. Ada dua perangkat bagaimana ide-ide tersebut dapat diterjemahkan dalam teks berita.Pertama, framing device (perangkat framing), dan reasoning device (perangkat penalaran) yaitu sebuah gagasan tidak hanya berisi kata atau kalimat, gagasan itu juga selalu ditandai oleh dasar pembenar tertentu, alasan tertentu dan sebagainya.

\section{FRAME}

Central organizing idea for making sense of relevant events, suggesting what is at issues

\begin{tabular}{|c|c|}
\hline $\begin{array}{l}\text { FRAMING DEVICES } \\
\text { (Perangkat Framing) }\end{array}$ & $\begin{array}{l}\text { REASONING DEVICES } \\
\text { (Perangkat Penalaran) }\end{array}$ \\
\hline $\begin{array}{lll}\text { Metaphors } & \text { (Perumpamaan } & \text { atau } \\
\text { pengandaian) } & & \\
\end{array}$ & Roots (Sebab-Akibat) \\
\hline $\begin{array}{l}\text { Catchphrases (Frase yang menarik, } \\
\text { kontras, menonjol dalam suatu wacana. } \\
\text { Ini umumnya berupa jargon atau slogan) }\end{array}$ & $\begin{array}{l}\text { Appeal to Principle (Premis dasar, } \\
\text { klaim moral) }\end{array}$ \\
\hline $\begin{array}{l}\text { Exemplar (Mengaitkan bingkai dengan } \\
\text { contoh, uraian. Bisa teori atau } \\
\text { perbandingan yang memperjelas } \\
\text { bingkai) }\end{array}$ & $\begin{array}{l}\text { Consequences (Efek atau konsekuensi } \\
\text { yang didapat dari bingkai) }\end{array}$ \\
\hline $\begin{array}{l}\text { Depictions (Penggambaran isu bersifat } \\
\text { konotatif, berupa kosakata, label) }\end{array}$ & \\
\hline $\begin{array}{l}\text { Visual Images (Gambar, grafik, citra } \\
\text { pendukung pesan yang ingin } \\
\text { disampaikan }\end{array}$ & \\
\hline
\end{tabular}

\section{Hasil Temuan dan Analisis}

Berdasarkan dari pemberitaan yang dilakukan oleh TvOne terkait penggerebekan asrama Papua di Surabaya tanggal 17 Agustus 2019 dengan menggunakan perangkat framing dari Gamson, dan media TvOne secara gamblang menunjukkan framingnya lewat berita yang dihasilkan. 
Pertama dari berita pertama yang datang dari program Kabar Utama dengan framing yang menghasilkan berita bahwa penggerebekan dan tindakan pengepungan ormas adalah hal yang wajar. Hal ini terlihat dari Framing devices dan Reasoning devices yang menyatakan sudah seharusnya dan sewajarnya pihak aparat melakukan penggerebekan dan pengamanan terhadap mahasiswa Papua yang kala itu bungkam atas apa yang terjadi. Dan dari berita yang kedua yaitu berita dari program Kabar Siang condong menyudutkan pihak mahasiswa Papua dan menunjukkan kontranya terhadap kubu tersebut. Dapat diteliti bersama di berita ini terdapat banyak spekulasi-spekulasi dari pihak berwajib ataupun narasumber-narasumber merugikan pihak mahasiswa. Dan TvOne cenderung mengambil sudut pandang kontra terhadap pihak mahasiswa.

Menurut KBBI, Nasionalisme sendiri adalah semangat cinta tanah air, dan rasa kebangsaan bangsa, dan juga menghormati bangsa. Diragukan akan rasa nasionalis oleh banyak pihak bukanlah hal mudah. Mengingat pada pemberitaan TvOne maupun Ormas di Surabaya pun turut menentang kehadiran para mahasiswa ini. Dengan pemberitaan yang telah disertai efek framing ini pun tentu akan lebih memojokkan pihak mahasiswa. Membuktikan bahwa ideologi media TvOne yang dicurahkan dalam bentuk visi misi yang menjurus pada mencerdaskan bangsa . Dan salah satunya adalah dengan membangun rasa nasionalis, terlebih jika melihat rekam jejak konglomerasi TvOne sendiri yang didominasi oleh anggota politik di Indonesia. Sesuai dengan teori Ideologi media dan Hirarki media, dengan adanya pemberitaan mengenai penggerebekan asrama mahasiswa Papua di Surabaya ini TvOne membuktikan secara implisit bahwa ia memegang teguh keyakinannya dan juga mengimplementasikan bahwa konten pemberitaan akan sangat sulit menjadi objektif, mengingat bahwa konten berita akan lebih condong pada kepentingan komunikator dalam menjalankan propaganda.

Analisis ini didukung dengan hasil wawancara bersama Jamalul Insan yang Menjabat sebagai Anggota Dewan Pers, Ketua Komisi Pendidikan, Pelatihan \& Pengembangan Profesi Pers Dewan Pers Periode 2019 - 2022. Beliau berpendapat bahwa tayangan berita pada tanggal 17 Agustus 2019 di TvOne ini memang seharusnya tidak menggabungkan konflik yang satu dengan yang lain. Termasuk dengan konflik pada tanggal 1 Desember yang lalu yang membuat framing yang terjadi menjadi semakin rumit dan menyangkut pada rasa nasionalis.

\section{Simpulan}

Dari hasil analisis pada bab sebelumnya, penulis dapat menyimpulkan bahwa framing dilakukan oleh media TvOne dengan bertamengkan latar belakang Pihak Mahasiswa Papua yang pernah melakukan aksi anti-nasionalis juga sebelumnya yang membuat pihak tersebut seakan pantas diperlakukan begitu baik oleh ormas Surabaya bahkan masyarakat di seluruh negeri nusantara, karena memang pada dasarnya mahasiswa tersebut sudah tidak menanamkan rasa nasionalis pada diri mereka.

Dengan hasil analisa ini pula penulis dapat menyimpulkan bahwa ideologi media akan sangat memegang penuh ke arah mana pemberitaan itu berlabuh. Dengan ideologi media yang sangat kokoh yaitu pemilik media juga merupakan ketua di partai kedua terbesar di Indonesia membuatnya sangat menjunjung tinggi nasionalisme, dan sangat tidak dapat mentolerir segala bentuk percobaan perpecahan yang mungkin terjadi. 


\section{Ucapan Terima Kasih}

Atas terselesaikannya penelitian ini, peneliti mengucapkan terima kasih kepada orang tua yang memberikan doa dan dukungan, serta teman-teman yang telah menemani dan membantu peneliti dalam penyusunan skripsi ini.

\section{Daftar Pustaka}

Arikunto, S. (2009). Prosedur Penelitian Suatu Pendekatan Praktik, Edisi Revisi 6. Jakarta : Rineka Cipta.

Bungin, Burhan. (2010). Penelitian Kualitatif: Komunikasi, Ekonomi, Kebijakan Publik dan Ilmu Sosial Lainnya. Jakarta: Kencana

Eriyanto. (2002). Analisis Framing: Konstruksi, Ideologi, dan Politik Media. Yogyakarta: Penerbitan Lkis.

Fadiyah, Dina. (2014). Analisis Framing Pemberitaan Ahok vs Lulung dalam Konflik Penertiban PKL di Pasar Tanah Abang Jakarta Pusat dalam Media Online Detik.com. Jurnal AL-AZHAR INDONESIA SERI PRANATA SOSIAL, Vol . 2, No. 3, Maret 2014

Karman, Karman. (2013). Media Massa dan Konstruksi Realitas. Jurnal Studi Komunikasi dan Media, Vol.17, no.2, (2013) pp. 173-186

Moleong, Lexy J. (2011). Metodologi Penelitian Kualitatif. Bandung: PT Remaja Rosdakarya

Nurudin. (2011). Pengantar Komunikasi Massa. Jakarta: Raja Grafindo Persada

Rahmat, Jalaludin. (2011). Psikologi Komunikasi. Bandung: Remaja Rosdakarya

Romli, Khomsahrial. (2016). Komunikasi Massa. Jakarta: PT Gramedia

Rizki, Sri, Wati, Juni. (2016). Kepemilikan Media dan Ideologi Pemberitaan. Ed.1/Ct.1 Yogyakarta.

Sudibyo, Agus. (2001). Politik Media dan Pertarungan Wacana. LKiS Ct

Sugiyono. (2015). Metode Penelitian Kualitatif. Bandung: Alfabeta 